\title{
Pengaruh Deep Breathing Exercise dan Terapi Musik Religi terhadap Tekanan Darah Pasien Hipertensi
}

\author{
Noor Fitriyani ${ }^{1}$, Fakhrudin Nasrul Sani ${ }^{2}$ \\ 1. Universitas Kusuma Husada Surakarta, email: pipitnizam87@gmail.com \\ 2. Universitas Kusuma Husada Surakarta, email: fakhrudin_ns@ymail.com
}

\begin{abstract}
Abstrak. Kasus hipertensi di Indonesia tahun 2018 meningkat 8,3 \% dari tahun sebelumnya, disebabkan penderita merasa sudah sehat dan riwayat minum obat tidak rutin. Meningkatnya prevalensi penderita hipertensi setiap tahunnya, penting dilakukan upaya dalam mengontrol tekanan darah. Kombinasi management non farmakologis dengan Deep Breathing Exercise dan Terapi Musik Religi sebagai salah satu upaya yang dapat dilakukan. Tujuan penelitian mengetahui pengaruh deep breathing exercise dan terapi musik religi terhadap tekanan darah Pasien hipertensi. Penelitian ini merupakan quasy eksperiment dengan desain pre test and post test without control. Sampel penelitian sejumlah 20 lansia dengan teknik pengambilan sampel total sampling. Uji normalitas data penelitian dengan menggunakan shapiro wilk dengan hasil data berdistribusi tidak normal sehingga uji korelasi menggunakan uji wilcoxon test. Hasil penelitian didapatkan rata-rata tekanan darah responden sebelum dan sesudah diberikan terapi deep breathing exercise dan terapi musik religi tekanan darah sistolik $161,00 \mathrm{mmHg}$ menjadi 148,50 $\mathrm{mmHg}$ dan diastolik 99,00 $\mathrm{mmHg}$ menjadi $89,50 \mathrm{mmHg}$. Hasil analisa uji korelasi menunjukkan ada pengaruh pemberian deep breathing exercise dan terapi musik religi terhadap tekanan darah pasien hipertensi, ditunjukkan dengan nilai $p$-value $=0,000(\mathrm{p}$-value $<0,05)$.
\end{abstract}

Kata kunci: Deep Breathing Exercise, Musik Religi, Hipertensi

\section{The Effect of Deep Breathing Exercise and Religious Music Therapy on Blood Pressure in Hypertensive Patients}

\begin{abstract}
Hypertension sufferers in 2018 , increased by $8.3 \%$ compared to the previous year because of the healthy patient feeling and a history of irregular taking medication. It is important to conduct actions in controlling blood pressure because of the increasing prevalence of hypertension sufferers every year. The combination of non-pharmacological management with a deep breathing exercise and religious music therapy is the effort that can be performed. The research objective was to identify the effect of deep breathing exercise and religious music therapy on blood pressure in hypertensive patients. This research adopted the quasi-experimental research method with pre- and post-test without a control group. A total sampling technique was applied to determine its samples, which consisted of 20 elderly. The normality test of research data applied the Shapiro Wilk with abnormal distribution results therefore the correlation test used the Wilcoxon test. The result revealed that the average blood pressure of respondents in pre and post- Deep Breathing exercise therapy and Religious Music therapy presented a systolic blood pressure of $161.00 \mathrm{mmHg}$ to $148.50 \mathrm{mmHg}$ and diastolic $99.00 \mathrm{mmHg}$ to $89.50 \mathrm{mmHg}$. The results of the correlation test analysis indicated that there was an effect of deep breathing exercise and religious music therapy on the blood pressure of hypertensive patients as indicated by the p-value = 0,000 (p-value <0.05). There is an effect of providing Deep Breathing Exercise and Religious Music therapy on the blood pressure of hypertensive patients as indicated by a p-value $=0,000$ (p-value $<0.05$ ).
\end{abstract}

Keywords: Deep Breathing Exercise, Religious Music, Hypertension. 


\section{Pendahuluan}

Hipertensi merupakan salah satu penyakit degeneratif, seiring bertambahnya umur dan gaya hidup individu (Triyanto, 2014). Kasus hipertensi di Indonesia tahun 2018 meningkat $8,3 \%$ dari tahun sebelumnya, disebabkan penderita merasa sudah sehat dan riwayat minum obat tidak rutin (Riskesdas, 2018). Peningkatan penderita hipertensi ditahun sebelumnya diperlukan intervensi yang tepat dalam mengontrol tekanan darah.

Penelitian oleh Hartanti, Wardana, \& Fajar (2016); Janet \& Gowri (2017) bahwa penerapan deep breathing exercise dapat menurunkan tekanan darah sistolik $18.46 \%$ dan tekanan diastolik $6.54 \%$ pada pasien Hipertensi. Penerapan deep breathing exercise sebabkan kardiopulmonari meregang, selanjutnya menstimulasi di arkus aorta, sinus karotis menuju ke medulla oblongata dan merangsang saraf parasimpatis yang berdampak menurunnya kontraktilitas miokardium, dilatasi pembuluh darah sehingga tekanan darah sistolik dan diastolik mengalami penurunan (Muttaqin, 2009).

Penerapan management lainnya untuk menurunkan tekanan darah dengan terapi musik. Hasil penelitian Mahatinadar dan Kahirun (2017), tentang pengaruh terapi musik klasik terhadap penurunan tekanan darah pada lansia dengan hipertensi didapatkan hasil ada pengaruh penurunan tekanan darah pada lansia dengan hipertensi. Musik melalui iramanya menurunkan kadar kortisol, menyebabkan pembuluh darah meregang dan mempengaruhi saraf simpatis sehingga memberikan efek rileks dan berkonstribusi terhadap penurunan tekanan darah (Djohan, 2016). Kombinasi intervensi relaksasi otot progresif dan terapi musik efektif dalam menurunkan tekanan darah pasien hipertensi (Niken, Dwi, dan Etty, 2017).

Hasil studi pendahuluan di Posyandu Mawar 5 Desa Grogol, Sukoharjo dengan wawancara kepada lansia dengan hipertensi bahwa penatalaksanaan yang diberikan pada pasien hanya menggunakan pengobatan farmakologis, sedangkan pengobatan non farmakologis belum ada. Pengobatan farmakologis dalam jangka waktu lama akan memberikan efek samping. Management pendukung secara non farmakologi dan ketepatan kombinasi diperlukan sebagai alternatif yang efektif dalam menurunkan tekanan darah pasien hipertensi.

\section{Metode}

Metode penelitian ini kuantitatif menggunakan desain quasy eksperiment dengan pre test and post test without control dengan melakukan suatu intervensi pada satu kelompok tanpa pembanding (Dharma, 2011). Penelitian ini untuk mengetahui pengaruh deep breathing exercise dan terapi musik religi terhadap tekanan darah pasien hipertensi. Musik religi yang digunakan dalam penelitian adalah judul lagu "demi masa" yang dipopulerkan oleh group vokal nasyid raihan.

Populasi dalam penelitian ini lansia dengan hipertensi dan aktif mengikuti kegiatan di Posyandu Mawar 5 Desa Grogol sebanyak 23 lansia dengan jumlah 20 lansia diambil teknik total sampling. Kriteria sampel penelitian yakni Lansia dengan hipertensi, tidak mengalami dimensia, dan tidak ada gangguan pendengaran. Pelaksanaan pengambilan data dilakukan bulan Mei Juni 2019.

Data penelitian diambil dengan mengukur tekanan darah sebelum diberikan deep breathing exercise dan terapi musik religi kemudian diberikan tindakan deep breathing exercise dan 
terapi musik religi selama 3 hari selanjutnya dilakukan pengukuran tekanan darah kembali. Sebelum peneliti melakukan uji korelasi, maka dilakukan uji normalitas dengan menggunakan shapiro wilk. Hasil uji normalitas data pada penelitian ini menunjukkan data berdistribusi tidak normal sehingga uji korelasi (analisa bivariat) menggunakan uji wilcoxon test.

\section{Hasil Penelitian}

1. Analisa Univariat

a. Karakteristik responden berdasar umur, jenis kelamin, tingkat pendidikan, dan pekerjaan

Tabel 1 Karakteristik responden

\begin{tabular}{lcc}
\hline $\begin{array}{l}\text { Karakteristik } \\
\text { Responden }\end{array}$ & n & $\%$ \\
\hline $\begin{array}{l}\text { 1.Umur } \\
\text { 60-74tahun }\end{array}$ & 17 & 85,5 \\
75-90 tahun & 3 & 15,0 \\
\hline 2.Jenis Kelamin & & \\
Laki-laki & 7 & 35,5 \\
Perempuan & 13 & 65,0 \\
\hline 3. Tingkat Pendidikan & \\
SD & 4 & 20,0 \\
SMP & 10 & 50,3 \\
SMA & 3 & 15,0 \\
D3 & 3 & 15,0 \\
\hline 4. Pekerjaan & & \\
Wiraswasta & 5 & 25,0 \\
IRT & 12 & 60,0 \\
Pensiun & 3 & 15,0 \\
\hline
\end{tabular}

Karakteristik responden berdasar umur dengan presentase terbesar pada kelompok usia 60 - 74 tahun $(85,5 \%)$, berdasarkan jenis kelamin presentase terbesar pada jenis kelamin perempuan $(65,5 \%)$, berdasar tingkat pendidikan dengan presentase terbesar pada kelompok lulusan SMP (50,3\%), serta berdasar pekerjaan dengan presentase terbesar pada kelompok IRT $(60 \%)$. b. Tekanan darah sebelum dan setelah intervensi Deep Breathing Exercise dan Terapi Musik Religi Tabel 2 Tekanan darah sebelum dan setelah intervensi

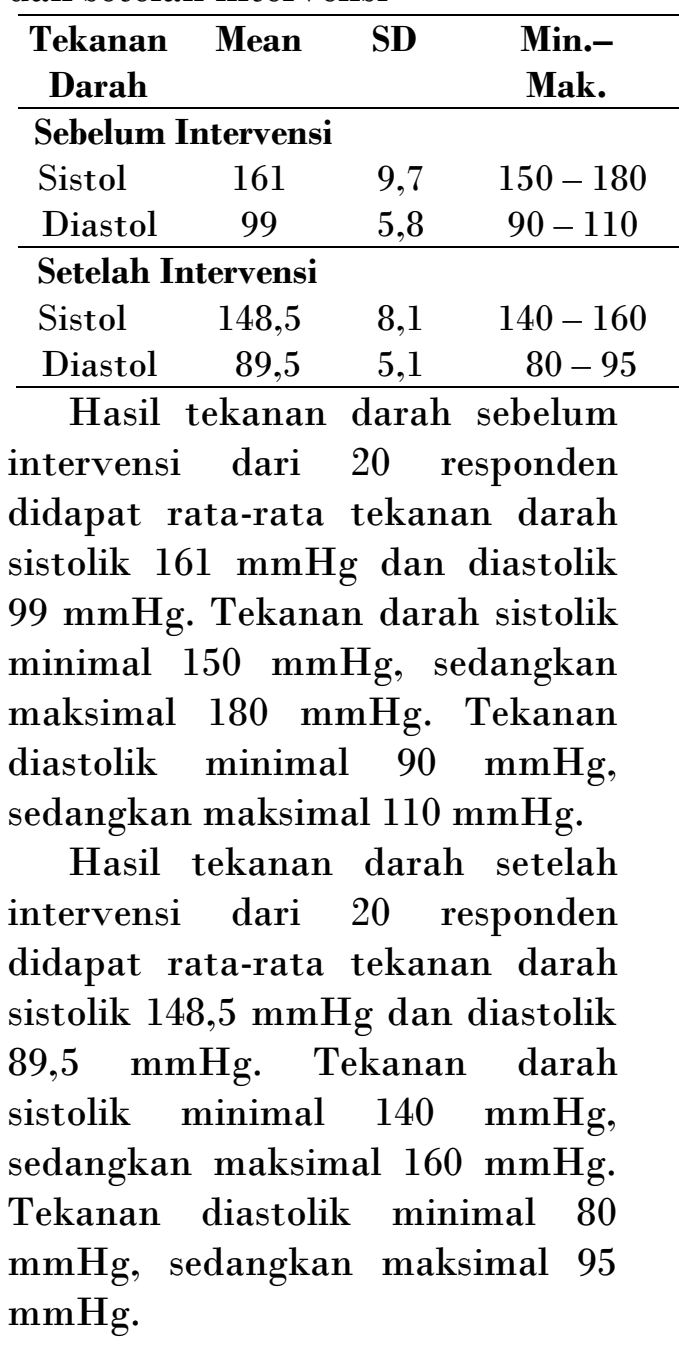

2. Analisa Bivariat

a. Uji Normalitas Data

Tabel 7 Uji Normalitas Data

\begin{tabular}{lccc}
\hline & \multicolumn{3}{c}{ Shapiro-Wilk } \\
\cline { 2 - 4 } & Statistic & df & Sig. \\
\hline $\begin{array}{l}\text { Pre } \\
\text { sistolik }\end{array}$ &, 841 & 20 &, 004 \\
$\begin{array}{l}\text { Post } \\
\text { sistolik }\end{array}$ &, 797 & 20 &, 001 \\
$\begin{array}{l}\text { Pre } \\
\text { diastolik }\end{array}$ &, 890 & 20 &, 027 \\
$\begin{array}{l}\text { Post } \\
\text { diastolik }\end{array}$ &, 824 & 20 &, 002 \\
\hline
\end{tabular}


Hasil uji normalitas data didapatkan nilai sig. $<0,05$ yakni data berdistribusi tidak normal

b. Uji Hipotesis Komparatif Tabel 8 Uji Wilcoxon Signed Ranks Test

\begin{tabular}{|c|c|c|}
\hline & $\begin{array}{c}\text { Tekanan } \\
\text { Darah }\end{array}$ & Post - Pre \\
\hline \multirow[t]{2}{*}{$\mathrm{Z}$} & Sistolik & $-3.987^{\mathrm{a}}$ \\
\hline & Diastolik & $-3.983^{a}$ \\
\hline \multirow{2}{*}{$\begin{array}{l}\text { Asymp. } \\
\text { Sig. (2- } \\
\text { tailed) }\end{array}$} & Sistolik & ,000 \\
\hline & Diastolik &, 000 \\
\hline$\overline{\mathrm{Uji}}$ & hipotesis & komparatif \\
\hline \multicolumn{3}{|c|}{$\begin{array}{l}\text { penelitian ini dengan uji wilcoxon } \\
\text { test. Nilai } p \text {-value }=0,000 \text { ( } p \text {-value } \\
<0,05 \text { ), maka dapat disimpulkan }\end{array}$} \\
\hline bahwa & terdapat & pengaruh \\
\hline pemberia & Deep & Breathing \\
\hline \multicolumn{3}{|c|}{$\begin{array}{l}\text { Exercise dan Terapi Musik Religi } \\
\text { terhadap tekanan darah pasien } \\
\text { hipertensi. }\end{array}$} \\
\hline
\end{tabular}

\section{Pembahasan}

Mayoritas responden penelitian ini pada kelompok usia $60-74$ tahun sebanyak 17 responden (85,5\%). Kesesuaian penelitian Bisnu, Kepel, dan Mulyadi (2017) bahwa lansia dengan hipertensi sebagian besar terjadi rentang usia 60- 74 tahun sebesar $42,6 \%$. Ketika seseorang bertambah usia dinding arteri mengalami penebalan akibat penumpukan zat kolagen pada lapisan otot, sehingga pembuluh darah mengalami vasokontriksi dan berdampak peningkatan tekanan darah sistolik maupun diastolik (Susilo dan Wulandari, 2011; Mahatinadar dan Kahirun, 2017). Seseorang dengan hipertensi lebih berisiko terjadi pada lansia seiring adanya pengaruh degenerasi.

Jenis kelamin responden pada penelitian ini menunjukkan sebagian besar berjenis kelamin perempuan sebanyak 13 responden $(65,5 \%)$. Hasil penelitian dilakukan Ervan (2013) pada lansia dengan hipertensi didapatkan $62,5 \%$ berjenis kelamin perempuan, hal tersebut ditunjukkan adanya kepedulian yang tinggi seorang perempuan untuk mengontrol kesehatan secara rutin ke pelayanan kesehatan. Perempuan memiliki kecenderungan mudah stress daripada laki-laki. Respon stres akan merangsang saraf simpatis dalam memicu kerja jantung dan menyebabkan peningkatan tekanan darah (Jose \& Almeida, 2013). Perempuan lebih berisiko terjadi hipertensi dibandingkan dengan laki-laki akibat terbatasnya perempuan melakukan aktivitas fisik jika dibandingkan laki-laki dan hal lainnya yakni tingkat kesadaran melakukan kontrol kesehatan diri, serta kecenderungan stress lebih tinggi.

Dilihat berdasarkan tingkat pendidikan responden pada penelitian ini presentase terbesar kelompok lulusan SMP sebanyak 10 responden $(50,3) \%$. Seseorang berisiko hipertensi karena tingkat pendidikan rendah sehingga mengalami kesulitan dan lambat menerima informasi (Mahatidanar, A. \& Khairun, 2017. Keterbatasan tingkat pengetahuan individu mempengaruhi management pelaksanaan pengendalian penyakit. Mayoritas pekerjaan responden penelitian ini adalah Ibu Rumah Tangga (IRT) sebanyak 12 responden (60\%). Niken, Dwi, dan Etty (2017), peningkatan frekuensi denyut jantung cenderung terjadi pada individu dengan keterbatasan melakukan aktivitas fisik sehingga memicu terjadinya peningkatan tekanan darah. IRT memiliki kecenderungan tidak adanya waktu melakukan aktivitas seperti olahraga dan saat ini aktivitas IRT dapat dilakukan dengan cepat dan praktis, sehingga mempengaruhi kemampuan otot jantung memompa darah dan berdampak peningkatan tekanan arteri. Pemicu terjadinya 
hipertensi pada individu akibat pola hidup tidak sehat.

Hasil penelitian didapatkan ratarata tekanan darah dari 20 responden pada pemberian intervensi deep breathing exercise dan terapi musik religi dengan tekanan sistolik $161 \mathrm{mmHg}$ menjadi 148,50 mmHg, sedangkan tekanan diastolik $99 \mathrm{mmHg}$ menjadi 89,50 mmHg. Pada hasil Tekanan sistolik minimal sebelum intervensi $150 \mathrm{mmHg}$, sedangkan tekanan sistolik maksimal setelah intervensi $140 \mathrm{mmHg}$. Tekanan diastolik minimal sebelum intervensi 90 $\mathrm{mmHg}$ dan setelah intervensi $80 \mathrm{mmHg}$. Selanjutnya pada hasil Tekanan sistolik maksimal sebelum intervensi $180 \mathrm{mmHg}$ dan setelah intervensi $160 \mathrm{mmHg}$. Tekanan diastolik maksimal sebelum intervensi $110 \mathrm{mmHg}$ dan setelah intervensi $95 \mathrm{mmHg}$. Pada hasil uji komparatif menunjukkan nilai hasil $p$ value $=0,000(\mathrm{p}$-value $<0,05)$ yang deep breathing exercise dan terapi musik religi terhadap tekanan darah pasien hipertensi.

Penelitian yang dilakukan Tri, Dody dan Wulandari (2014), bahwa pemberian musik klasik efektif dalam menurunkan tekanan darah sistolik dan diastolik pasien hipertensi, dimana rerata tekanan darah sistolik 148,32 $\mathrm{mmHg}$ menjadi $130,00 \mathrm{mmHg}$ dan diastolik $93,25 \mathrm{mmHg}$ menjadi $80,00 \mathrm{mmHg}$ setelah intervensi. Hasil penelitian yang sama oleh Sari, Miraswati, Rismadefi, (2014) bahwa pemberian terapi musik terhadap penurunan tekanan darah ibu dengan hipertensi dalam kehamilan menunjukkkan hasil efektif yakni penurunan tekanan darah sistolik 9,74 mmHg dan tekanan darah diastolik 7,73 mmHg setelah intervensi.

Intervensi deep breathing pada pasien hipertensi pada hasil penelitian Rini dan Insiyah (2013) menunjukkan bahwa adanya pengaruh pemberian tehnik deep breathing terhadap penurunan tekanan darah pasien hipertensi, yaitu berdasarkan nilai ratarata tekanan darah sistolik 177,33 mmHg menjadi $173,20 \quad \mathbf{m m H g}$ sedangkan tekanan diastol $95,87 \mathrm{mmHg}$ menjadi $90,57 \mathrm{mmHg}$ setelah pemberian intervensi. Penelitian dengan hasil sama dilakukan Rita, Desnanda, dan Rifki (2016), bahwa terapi relaksasi napas dalam efektif menurunkan tekanan darah (sistolik dan diastolik) pada pasien hipertensi yakni terjadi penurunan tekanan darah sitolik sebesar 18,46 $\mathrm{mmHg}$ dan diastolik sebesar 6,54 $\mathrm{mmHg}$.

Pelaksanaan intervensi penelitian ini dilakukan selama 3 hari secara berturut-turut dengan pemberian kombinasi 2 intervensi, yakni deep breathing exercise dengan musik religi pada 20 lansia, terbukti menunjukkan adanya tekanan darah. Kombinasi dari 2 tindakan yang dilakukan memberikan efek yang merilekskan. Menurut Damayanti (2013), ketika individu dalam kondisi rileks metabolisme tubuh berjalan lambat akibat mekanisme kontrol sistem syaraf pernafasan yang mempengaruhi kecepatan denyut jantung dan perubahan tekanan darah.

Kesesuain dengan hasil penelitian Sari, Miraswati, Rismadefi, (2014), bahwa intervensi dilakukan selama 3 hari secara berturut-turut dengan durasi selama 15 menit didapatkan hasil yang sama yakni efektif dalam menurunkan tekanan darah. Menurut Rini dan Insiyah (2009), terapi relaksasi nafas dalam sangat baik dilakukan setiap hari dikarenakan dapat membantu relaksasi otot tubuh terutama otot pembuluh darah dalam mempertahankan elastisitas pembuluh darah arteri sehingga mampu menurunkan tekanan darah. Pengaturan tekanan darah dengan mengurangi frekuensi bernafas 16-19 kali/ menit menjadi 10 kali atau kurang secara rutin selama 15 menit perharinya dapat membantu mengatur tekanan darah dan 
menurunkan tekanan darah 10-15 mmHg (Evelyn, 2011). Mekanisme deep breathing exercise terjadi peningkatan peregangan kardiopulmonar menuju ke medula oblongata yang merangsang saraf parasimpatis ke miokardium dan mengakibatkan penurunan tekanan darah (Muttaqin, 2009).

Pada penelitian ini, judul musik religi yang digunakan adalah "demi masa" yang dipopulerkan oleh grup vokal nasyid raihan. Makna yang terkandung dalam lirik lagu demi masa adalah bisa menyadarkan kita betapa tiap detik waktu selama hidup di dunia sangat berharga dan kita tidak pernah tahu berapa lama waktu yang diberikan selama hidup di dunia, sehingga memotivasi orang untuk lebih mendekatkan diri kepada sang pencipta dan memberikan motivasi bagi yang mendengar untuk cepat sembuh. Pemberian terapi musik religi secara fisiologis akan mempengaruhi impuls yang akan dikirimkan ke amiglada melalui gelombang otak sehingga memberikan ketenangan, kesabaran, tidak putus asa dan salalu optimis (Anny, Tri, dan Abdur; 2017). Dampak lainnya dari mendengarkan musik religi yakni nasehat-nasehat spiritual dapat meningkatkan pengharapan positif kepada individu yang mendengarkannya (Dani, 2010).

Menurut Rusdi dan Isnawati (2009), musik memicu sekresi hormon endorphin dan serotonin serta menghambat sekresi hormon stress seperti ACTH yang berdampak pada pengaturan tekanan darah. Musik religi merupakan jenis musik alkaline, yaitu musik dengan irama perlahan yang memberikan ketenangan dan dampak pada fisiologi tubuh sehingga mempengaruhi penurunan frekuensi jantung dan tekanan darah (El Rahmayati dan Ririn, 2017). Menurut peneliti responden dalam penelitian ini merupakan masyarakat yang religius, dimana nilai akan keyakinan dijaga dengan baik. Responden dalam penelitian ini adalah lansia, dimana dengan bertambahnya usia tingkat keyakinan semakin kuat akan keberadaan Tuhan Y.M.E., merasa memilki tempat untuk meletakkan semua beban kehidupan dan keyakinan akan mendapat pertolongan dari Tuhan Y.M.E.

\section{Simpulan}

Rata-rata tekanan darah responden sebelum dan sesudah diberikan terapi deep breathing exercise dan terapi musik religi tekanan darah sistolik 161,00 mmHg menjadi 148,50 $\mathrm{mmHg}$ dan diastolik 99,00 $\mathrm{mmHg}$ menjadi 89,50 mmHg. Berdasarkan hasil analisa data menggunakan uji wilcoxon test menunjukkan nilai $p$-value $=0,000(p$ value $<0,05)$ dapat disimpulkan terdapat pengaruh pemberian deep breathing exercise dan terapi musik religi terhadap tekanan darah pasien hipertensi.

\section{Ucapan Terimakasih}

Ucapan terimakasih diberikan kepada pihak yang telah membantu dalam kelancaran penelitian ini terutama Universitas Kusuma Husada (UKH) Surakrat sebagai pemberi dana, Tim LPPM UKH , Kader Posyandu Mawar 5 dan Responden penelitian.

\section{Daftar Pustaka}

Anny R.M., Tri S., Abdur R. Efektifitas Pemberian Terapi Musik Religi Nasyid "Demi Masa" dengan Penurunan Tingkat Kecemasan Pasien Pre Operasi dengan Regional Anastesi Sub Archnoid Blok di RS PKU Muhammadiyah Gubug. Jurnal Ilmu Keperawatan dan Kebidanan, Vol. 8 No.2 (2017) 11-18. 
Dharma, Kelana Kusuma. 2011. Metodologi Penelitian Keperawatan. Jakarta: Trans Info Media.

Niken F.A, Dwi N.K.W., dan Etty R. Penurunan Tekanan Darah Diastolik pada Lanjut Usia melalui Intervensi Relaksasi Otot Progresif dan Terapi Musik (RESIK). Jurnal Keperawatan Soedirman (The Soedirman Journal of Nursing), Volume 12, No.1 Maret (2017).

Bisnu M.I.K., Kepel B.J., dan Mulyadi. (2017). Hubungan Dukungan Keluarga Dengan Derajat Hipertensi Pada Pasien Hipertensi Di Puskesmas Ranomuut Kota Manado. $e$ Journal Keperawatan (e-KP) Volume 5 Nomor 1, Februari 2011.

Damayanti, D. (2013). Sembuh Total Diabetes, Asam Urat, Hipertensi tanpa obat. Yogyakarta: Pinang Merah Publisher.

Dani, Indriya R. 2010. Kekuatan Musik Religi Mengurai Cinta Merefleksi Iman Menuju Kebaikan Universal. Jakarta: PT Gramedia.

Djohan. 2016. Terapi musik teori dan aplikasi. Yogyakarta: Galang Press.

El Rahmayati dan Ririn S.H. Perbedaan Pengaruh Terapi Psikoreligius dengan Terapi Musi Klasik terhadap Kecemasan Pasien Pre Oeratif di RSUD dr. H. Abdul Moeloek Provinsi Lampung. Jurnal Kesehatan, Vol VIII No. 2, Agustus 2017, hlm 191-198.
Ervan, K.P. (2013). Pengaruh Latihan Nafas Dalam terhadap Perubahan Tekanan Darah pada Penderita Hipertensi di Wilayah Kecamatan Karas Kabupaten Magetan. Skirpsi. UMS. Surakarta.

Evelyn P. (2011). Buku Anatomi dan Fisiologi untuk Paramedis. Jakarta: Gramedia.

Hartanti, R.D., Wardana D.P., Fajar, R.A. Terapi Relaksasi Nafas Dalam Menurunkan Tekanan Darah Pasien Hipertensi. Jurnal Ilmiah Kesehatan. Vol 9 No.1. 2016.

Janet dan Gowri. Effectiveness of Deep Breathing Exercise on Blood Pressure among Patients with Hypertention. Int J Pharm Bio Sci 2017 Jan ; 8(1): (B) $256-260$.

Jose R. \& Almeida V.D. 2013 Effectiveness of Jacobson's Progressive Muscle Relaxation (JPMR) on Blood Pressure and Health Related Stress Level among Patients with Hypertension in a Selected Hospital of Mangalore. International Journal of Nursing Education, 5(2), 2013. $171-176$.

Mahatidanar, A. \& Khairun, N.B.. Pengaruh Musik Klasik Terhadap Penurunan Tekanan Darah pada Lansia Penderita Hipertensi. Jurnal Agromedicine, 4 (2). 2017. pp. 264-268. ISSN 2356-332X.

Muttaqin, Arif. (2009). Asuhan Keperawaatn Klien dengan Gangguan Sistem Kardiovaskuler. Jakarta: Salemba Medika.

Rini T.H. \& Insiyah. (2009). Penurunan 
tekanan darah menggunakan tehnik nafas dalam (deep breathing) pada pasien hipertensi di Puskesmas Bendosari Kabupaten Sukoharjo. Skripsi. Kemenkes Poltekkes Surakarta.

RitaD.H, Desnanda P.W, dan Rifki A.F. efektivitas terapi relaksasi napas dalam terhadap penurunan tekanan darah pada pasien dengan hipertensi. JIK, Vol. IX, NO 1, Maret, 2016.

Riskesdas. (2018). Potret Sehat Indonesia. Jakarta: Kementrian Kesehatan RI.

Rusdi dan Isnawati. (2009). Awas! Anda bisa mati cepat akibat Hipertensi dan Diabetes. Jogjakarta: Power Books.

Sari W., Misrawati, Rismadefi W. Efektifitas pemberian terapi musik terhadap penurunan tekanan darah pada ibu dengan hipertensi dalam kehamilan. JOM PSIK, Vol. 1 No. 2 Oktober, 2014.

Susilo, Y dan Wulandari, A. (2011). Cara Jitu Mengatasi Hipertensi. Yogyakarta: Graha Ilmu.

Triyanto. (2014). Pelayanan Keperawatan bagi Penderita Hipertensi. Yogyakarta : Graha Ilmu.

Tri Y.F, Dody S., Wulandari M. (2014). Perbedaan terapi musik klasik dan musik yang disukai terhadap tekanan darah pada pasien hipertensi di Di RSUD Dr. H. Soewondo Kendal. Skripsi UNDIP. Semarang. 